\title{
Phenols, flavonoids and antioxidant activity of Jatropha multifida L. collected in Pindamonhangaba, Sao Paulo State, Brazil
}

\begin{abstract}
A number of herbs belonging to the genus Jatropha of Euphorbiaceae family are noted for their medicinal benefits. It has already been observed the antibacterial, antiinflammatory, antifungal, antioxidant activity, anti-tumor and others. They are also employed as ornamental plants and energy crops. Qualitative and quantitative methods were used for the evaluation of total phenols and flavonoids in the latex and leaves extract of Jatropha multifida Linn and their antioxidant activity. This study was able to confirm the presence of phenols and flavonoids in the samples analyzed and its antioxidant activity corroborating the use of latex of the plant in the pharmaceutical industry.
\end{abstract}

Keywords: medicinal plant, Jatropha multifida, phytochemical composition, flavonoids, phenols, antioxidant activity
Volume 7 Issue 5 - 2018

\author{
Claudemir de Carvalho,' Letícia Vieira \\ Mariano, ${ }^{2}$ Vinícius S Negrão, ${ }^{3}$ Carolina \\ Passarelli Gonçalves, ${ }^{4}$ Maria Cristina \\ Marcucci ${ }^{5}$ \\ 'Coordination of Research, FUNVIC - Faculty of \\ Pindamonhangaba, Brazil \\ ${ }^{2}$ Pharmacognosy Laboratory, FUNVIC- Faculty of \\ Pindamonhangaba, Brazil \\ ${ }^{3}$ Quality Control Laboratory, Pindamonhangaba, Brazil \\ ${ }^{4}$ Pharmacy Institute, Anhanguera University of São Paulo, Brazil \\ ${ }^{5}$ Laboratory of Natural Products and Chemometrics, \\ Anhanguera University of São Paulo, Brazil
}

\begin{abstract}
Correspondence: Claudemir de Carvalho, Coordenadoria de Pesquisa Pós-Graduação e Extensão, FUNVIC - Faculdade de Pindamonhangaba, São Paulo, Brazil, Tel +55I 236488323, Email prof.clawdemircarvalho.pinda@funvic.edu.br
\end{abstract}

Received: August 02, 2017| Published: October 16, 2018

\section{Introduction}

Traditional medicinal plants have been recognized as a rich source of candidate compounds for the development of pharmaceuticals. ${ }^{1,2}$ The genus Jatropha belongs to the family Euphorbiaceae and has a great variety of species, among them J. multifida, J. curcas, $J$. molissima, J. gossypifolia that are currently the source of studies for the production of biodiesel and also for the medicinal character that have. ${ }^{3}$

Jatropha multifida (Linn), commonly called coral bush, is characterized as a shrub up to $1.30 \mathrm{~m}$ high, and can reach $7 \mathrm{~m}$ in its habitat. It has green leaves up to $17 \mathrm{~cm}$ long and $23 \mathrm{~cm}$ wide, multifidus stipules up to $2 \mathrm{~cm}$ long, red inflorescence up to $20 \mathrm{~cm}$ long, fruit up to $3 \mathrm{~cm}$ long and $2.5 \mathrm{~cm}$ in diameter. The entire plant has whitish latex, so leaves, stem, bark and roots of the Jatropha plant have been used in ethno-medicines for a long time principally in India ${ }^{4}$ and in Africa. ${ }^{5} \mathrm{~J}$. multifida is used in African folk medicine for the treatment of infection, pain, fever, various inflammatory conditions, tumor and tumor related diseases. 6

Chemical investigation of the $J$. multifida has led to the isolation of nine diterpenoids, including a new jatromulone $\mathrm{A}$, four podocarpane diterpenoids, two lathyrane-type diterpenoids and two dinorditerpenoids. ${ }^{7}$

Among the components already isolated from different parts of the plant and identified are diterpenes $15-O$-acetyl japodagrone, (4E)jatrogrosidentadione acetate, (4E)-jatrogrossidentadione, multifidone, multidione, multifolone. ${ }^{8}$ Earlier examination of the latex of the plant afforded some cyclic peptides, phenolics and glucosides. ${ }^{9}$
The Genus Jatropha is a rich source of phytochemicals that can be utilized in nutritional, agricultural and pharmaceutical industries. The pharmacological properties presented by the plant are diverse, being the latex produced by it the substance that presented the highest therapeutic potential described in the literature to date.

The plant is known to possess different medicinal properties including antimicrobial activity, ${ }^{10,11}$ anti-inflammatory and antioxidante activities, ${ }^{12}$ phytochemical and larvicidal properties, ${ }^{13}$ antioxidant, hemolytic and toxic. ${ }^{14}$ The stems of J. multifida could be regarded as an anti-influenza herbal medicine as well as a potential crude drug source for the development of anti-influenza compounds. ${ }^{15}$

According to Adesola and Adetunji ${ }^{16}$ the alcohol extract obtained from leaves, stems or barks showed antifungal activity in a study against Candida albicans. The studies of Hirota et al. ${ }^{14}$ showed that from the methanolic extract of the leaves three di-C-glycosidic biflavones were identified and the extract presented significant analgesic and antiinflammatory properties compared to Indomethacin, in addition to being hypotensive.

The leaves, the latex and the fruits of this plant are used in the treatment of infected wounds, skin infection and as a cicatrizing, ulcers, oral thrush, constipation and fever. ${ }^{17}$ Roots and stem are used as anticancer, antitumor, cytotoxic, atimalarial, antileshmanial, antimicrobial, insecticidal and molluscidal because of the diterpenoid Lathyrane. ${ }^{18}$

\section{Materials and methods}

In this research were used spectrophotometric methods to determine the content of phenols and flavonoids of the hydroalcoholic 
Jatropha multifida leaves extract and latex. The evaluation of the antioxidant activity was based upon the use of the stable free radical diphenylpicrylhydrazyl (DPPH), which is reduced in the presence of antioxidant substance. ${ }^{19}$

The leaves of $J$. multifida were collected from six adult specimens of the plant, in a residence of the municipality of Pindamonhangaba, Sao Paulo State, Brazil. Identification was made by Dr. Gokithi Akisue and sent an exsiccate to the Herbarium of the University of Sao Paulo-USP.

To obtain the hydroalcoholic extract were used $100 \mathrm{~g}$ of a pool of fresh leaves of the plants. The leaves were washed thoroughly with normal tap water followed by sterile distilled water. Then the leaves were shade dried at room temperature and turned into a fine powder after well grounding using grinding machine. ${ }^{20}$ Of the powdered leaves, crude extract was prepared by percolation; the solvents used were $50 \%$ ethyl alcohol $95 \%$ and $50 \%$ water. Starting with $100 \mathrm{~g}$ of the leaves, $200 \mathrm{~mL}$ of concentrated extract was obtained. The latex was obtained by dripping after cutting small branches of the plants. The hydroalcoholic extract and the latex were used for the research of flavonoids and phenols, and verification of antioxidant activity.

\section{Preliminary phytochemical analysis}

Test for flavonoid: $1 \mathrm{~mL}$ of $2 \mathrm{~N} \mathrm{NaOH}$ was added to $1 \mathrm{~mL}$ of leaves extract and latex, than the result of yellow color was taken as indicator for the presence of flavonoids.

Test for phenol: To $1 \mathrm{~mL}$ of leaves extract and $1 \mathrm{~mL}$ of latex, $1 \mathrm{~mL}$ of sodium carbonate was added. To that $1 \mathrm{~mL}$ of folin was added. Formation of blue or green color indicates the presence of Phenols.

\section{Estimation of total flavonoid content in leaves extract and latex of Jatropha multifida}

\section{a. Construction of the standard curve}

Metanolic solutions of quercetin at concentrations of 3.0, $4.0 \mathrm{ng}$ up to $10.0 \mu \mathrm{g} / \mathrm{ml}$ were prepared. It was transferred to a $10 \mathrm{~mL}$ volumetric flask containing approximately $5 \mathrm{~mL}$ of methanol, an aliquot corresponding to each quercetin concentration and $200 \mu \mathrm{L}$ of the aluminum chloride solution. The final volume was set at $20^{\circ} \mathrm{C}$. After the time of 30 minutes, the spectrophotometer - FEMTO Model Cirrus 80 - was read at $425 \mathrm{~nm}$. The equation of the standard curve was calculated by the least squares method. ${ }^{21}$

\section{b. Flavonoid content in the hydroalcoholic extract and in the} latex

A stock solution was made up with $100 \mu \mathrm{L}$ of the hydroalcoholic extract/latex in $10 \mathrm{~mL}$ volumetric flask and completed with methanol until the meniscus. Then the procedures of item a were repeated. The procedure was done in triplicate. ${ }^{21}$

\section{Estimation of total phenol content in leaves extract and latex of Jatropha multifida}

\section{a. Construction of the standard curve}

A standard curve was constructed with gallic acid at concentrations of $3.0,4.0 \mu \mathrm{g}$ up to $12.0 \mu \mathrm{g} / \mathrm{ml}$. It was transferred into a $10 \mathrm{~mL}$ volumetric flask containing approximately $5 \mathrm{~mL}$ of distilled water an aliquot corresponding to each phenol solution concentration and
$800 \mu \mathrm{L}$ of the Folin-Ciocalteau reagent. Within about 4 minutes, $1.2 \mathrm{~mL}$ of the $20 \%$ sodium carbonate-tartrate solution was added. It was allowed to react in a bath at $20^{\circ} \mathrm{C}$ for 2 hours and the final volume was adjusted, stirred for a few seconds. The absorbance was measured at $760 \mathrm{~nm}$ in a UV-Visible Spectrophotometer, then the total phenolic content of the samples were estimated using mg Gallic acid equivalents (GAE)/g. ${ }^{20,21}$

\section{b. Total phenol content in the hydroalcoholic extract and latex}

Stock solution was prepared with $1 \mathrm{~mL}$ of hydroalcoholic extract/ latex in a $100 \mathrm{~mL}$ flask and the volume was quenched with water. Then the procedures of item a were repeated. The procedure was done in triplicate. ${ }^{21}$

\section{Verification of antioxidant activity}

For the verification of the antioxidant activity of the extract, the soluble solids content was first performed to know the exact concentration of the same. The latex was not necessary because it was used in its crude form.

For the determination of the soluble solids content, some adaptations of the method used were made. A $25 \mathrm{~mL}$ beaker containing $5 \mathrm{~mL}$ of the extract was taken to the oven at $60^{\circ} \mathrm{C}$ for two hours. After cooling in desiccator, the weighing was done; this procedure was repeated until constant weight. The soluble solids content was calculated according to the following formula:

$$
\% \text { soluble solids }(m / v)=\frac{\left.m_{2}-f\right) \times 100}{v_{a}}
$$

$\mathrm{m}_{2}$ : final beaker mass with dry extract, $\mathrm{f}$ : initial mass of the beaker; Va: volume of the aliquot

After the previous procedure two dilutions were made for the extract, one to $1 \%$ and another to $0.01 \% \mathrm{~V} / \mathrm{V}$; for the latex only $0.01 \%$. In eleven tubes numbered from zero to ten, the volume of alcohol, extract/latex in each tube was added. Tube number zero was the control group. The volume of DPPH was added to the first tube and waited 1 minute. DPPH was added to the other tubes every 1 minute. The tubes were shaken. The spectrophotometer was read at $517 \mathrm{~nm}, 30$ minutes after the addition of DPPH in the 1st tube. The absorbance $(\%)$ versus concentration of extract/latex $(\mu \mathrm{g} / \mathrm{mL})$ was plotted. The EC50 was calculated by the least squares method. ${ }^{21}$ The experiment was carried out in triplicates.

\section{Results and discussion}

\section{Phenol and flavonoid contents}

Table 1 shows the values of total of flavonoid and phenols found in the latex and hydroalcoholic extract of J. multifida L.

Table I Total phenols and flavonoids in leaves extract and latex of J. multifida $\mathrm{L}$.

\begin{tabular}{lll}
\hline & Latex & Leaves extract \\
\hline Phenols (a) & 4,808 & 0,130 \\
Flavonoids (b) & 0,000 & 2,322
\end{tabular}

a: Determined as gallic acid (mg GAE/g)

b: Determined as quecertin with $\mathrm{AlCl}_{3}(\mathrm{mg} / \mathrm{g})$ 
The latex presented $4.808 \%$ of total phenols, while the value of flavonoids was null. In the extract, however, there is an inversion in these values, presenting less than $0.5 \%$ of phenols and a higher value of flavonoids $2,322 \%$. The results obtained for the extract may have been influenced by the solvent used. ${ }^{20}$ Rampadarath et al. ${ }^{13}$ also showed the effect of solvent on phytochemical extraction.

The qualitative and quantitative results of phenol and flavonoid compounds in latex and leaves extract of $J$. multifida are in concordance with that obtained by Rampadarath et al. ${ }^{13}$

\section{Soluble solids}

The soluble solids content found in the hydroalcoholic extract of J. multifida was $45.61 \%$.

\section{Antioxidant activity}

The results were given in EC50 $(\mu \mathrm{g} / \mathrm{mL})$, which is equivalent to the amount of extract required to reduce the DPPH radical by $50 \% .^{19}$

As showed in Table 2, the latex showed antioxidant activity with EC50 value of $3.44 \mu \mathrm{g} / \mathrm{mL}$ while leaves extract $0.01 \%$ and leaves extract $1 \%$ showed $0.0 \mu \mathrm{g} / \mathrm{mL}$ and $1,530.75 \mu \mathrm{g} / \mathrm{mL}$, respectively.

Table 2 Antioxidant activity of leaves extract and latex of J. multifida L. expressed in $\mu g / \mathrm{mL}$ of DPPH

\begin{tabular}{llll}
\hline & Latex $\mathbf{0 . 0 1 \%}$ & $\begin{array}{l}\text { Leaves } \\
\text { extract } \mathbf{0 . 0 1 \%}\end{array}$ & $\begin{array}{l}\text { Leaves } \\
\text { extract 1\%* }\end{array}$ \\
\hline $\begin{array}{l}\text { Antioxidant } \\
\text { activity }\end{array}$ & 3.44 & 0 & $\mathrm{I}, 530.75$ \\
\hline
\end{tabular}

*The leaves extract was tested at $1.0 \%$ because in its lower concentration did not present activity

Compared to the Green Propolis extract - EC50 15.71 $\mu \mathrm{g} / \mathrm{mL},^{22}$ and to Ginkgo biloba L extract, that has EC50 $38.91 \mu \mathrm{g} / \mathrm{mL}$ and is considered by Mensor et al..$^{23}$ as an extract of high antioxidant activity, it is clear that the latex of J. multifida appears to be an excellent antioxidant. It should be noted that the lower the value of DPPH, the higher the antioxidant activity. ${ }^{19}$

The antioxidant activity is characterized by the inhibition or retardation of the oxidation of substances susceptible to this type of reaction, which consists in the elimination or capture of free radicals. Because synthetic antioxidants are toxic and expensive, the search for natural antioxidants has been increasing in studies and research. This activity in natural compounds has been related to the presence of phenolic compounds found in medicinal plants. ${ }^{24}$

Jatropha plants are described to have several chemical constituents as alkaloids, cyclic peptides, terpenes (a monoterpene, sesquiterpenes, diterpenes and triterpenes), flavonoids, lignans, coumarins, coumarinolignoids, a non-cyanogenic glucoside, phloroglucinols, ester ferulates, phenolics, deoxypreussomerins and fatty acids ${ }^{17}$ which makes them of high interest for the agricultural nutritional and pharmaceutical industries. $^{3}$

Factors as climatic, seasonal and geographical conditions, age of plant, humidity of the harvested plant material, extraction technique, and the existence of chemo type may result in discrepancy in the composition of extracts of plants, ${ }^{25}$ which necessitates further studies with samples of specimens from different areas.
Toxic effects have been reported after ingestion of $J$. multifida seeds, which contains a toxalbumin capable of causing agglutination and hemolysis of red blood cells and is also detrimental to other cells. This indicates that the seeds probably should not be used in the production of medicines. ${ }^{26}$

\section{Conclusion}

There is variation in the chemical composition of phenols and flavonoids between leaf extract and latex of $J$. multifida, but this difference can be related to the solvent used in the extraction, and more studies are necessary to determine it with certainty. In relation to the antioxidant activity, J. multifida latex presents very expressive and promising activity, but it needs more research on it. Also the presence of phenolic compounds acts as a factor for the antioxidant activity.

\section{Acknowledgements}

None.

\section{Conflict of interest}

The author declares that there is no conflict of interest.

\section{References}

1. Molinari G. Natural products in drug discovery: present status and perspectives. Adv Exp Med Biol. 2009;655:13-27.

2. Harvey AL, Edrada-Ebel R, Quinn RJ. The re-emergence of natural products for drug discovery in the genomics era. Nat Rev Drug Discov. 2015;14(2):111-129.

3. Devappa RK, Makkar HPS, Becker. Jatropha toxicity-a review. J Toxicol Environ Health B Crit Rev. 2010;13:476-507.

4. Duke JA, Ayensu ES. Medicinal plants of China. Reference Publications: USA; 1985.

5. Burkill HM. The useful plants of West Tropical Africa. Royal Botanical Gardens; 1994:90-94

6. Falodun A, Igbe I, Erharuyi O, et al. Chemical characterization, antiinflammatory and analgesic properties of Jatropha multifida root bark. $J$ Appl Sci Environ Manage. 2013;17(3):357-362.

7. Zhu JY, Chun Yang Zhang CY, et al. Diterpenoids with thioredoxin reductase inhibitory activities from Jatropha multifida. Nat Prod Res. 2017;31(23):2753-2758.

8. Devappa RK, Makkar HPS, Becker K. Jatropha Diterpenes: a Review. $J$ Am Oil Chem Soc. 2011;88(3):301-322.

9. Van den Berg AJJ, Horsten SFAJ, Van Den Bosch JJK, et al. Multifidin-a cyanoglucoside in the latex of Jatropha multifida. Phytochemistry. 1995;40(2):597-598.

10. Aiyelaagbe OO. Antimicrobial activity of Jatropha multifida roots. Fitoterapia. 2001;72(5):544-546.

11. Aiyelaagbe OO, Oguntuase BJ, Arimah BD, et al. The antimicrobial activity of Jatropha multifida extracts and chromatographic fractions against sexually transmitted infections. J Med Sci. 2008;8(2):143-147.

12. Anani K, Adjarah Y, Ameyapoh Y, et al. Antimicrobial, anti-inflammatory and antioxidante activities of Jatropha multifida L. (Euphorbiaceae). Pharmacognosy Res. 2016;8(2):142-146.

13. Rampadarath S, Puchooa D, Ranghoo-Sanmukhiya VM. Antimicrobial, phytochemical and larvicidal properties of Jatropha multifida Linn. Asian Pac J Trop Med. 2014;7(Suppl 1):S380-S383. 
14. Hirota BCK, Miyazaki CMS, Mercali CA, et al. C-glycosyl flavones and a comparative study of the antioxidant, hemolytic and toxic potential of Jatropha multifida leaves and bark. Int J Phytomed. 2012;4(1):01-05.

15. Shoji M, Woo SY, Masuda A, et al. Anti-influenza virus activity of extracts from the stems of Jatropha multifida Linn. collected in Myanmar. BMC Complement Altern Med. 2017;17(1):96.

16. Adesola AT, Adetunji OO. The efficacy of Jatropha multifida in the management of oral candidiasis: a preliminary study. The Internet Journal of Alternative Medicine. 2007;4(1).

17. Sabandar CW, Ahmat N, Jaafar FM, et al. Medicinal property, phytochemistry and pharmacology of several Jatropha species (Euphorbiaceae): A review. Phytochemistry. 2013;85:7-29.

18. Falodun A, Imieje V, Erharuyi O, et al. Isolation of antileishmanial, antimalarial and antimicrobial metabolites from Jatropha multifida. Asian Pac J Trop Biomed. 2014;4(5):374-378.

19. Molyneux P. The use of the stable free radical diphenylpicrylhydrazyl (DPPH) for estimating antioxidant activity. Songklanakarin J Sci Technol. 2004;26(2):211-219.
20. Amabye TG, Bezabh AM, Mekonen F. Phytochemical Constituents and Antioxidant Activity of Delonix elata L. in Flower Extract. J Anal Pharm Res. 2016;2(1):00006.

21. Bankova VS, Marcucci MC. Standardization of Propolis: Present Status and Perspectives. Bee World. 2000;81(4):182-188.

22. Kumazawa S, Hamasaka T, Nakayama T. Antioxidant activity of propolis of various geographic origins. Food Chemistry. 2004;84(3):329-339.

23. Mensor LL, Menezes FS, Leitão GG, et al. Screnning of Brazilian plant extracts for antioxidant activiy by the use of DPPH free radical method. Phytother Res. 2001;53:127-130.

24. Okoh SO, Iweriebor BC, Okoh OO, et al. Antibacterial and Antioxidant Properties of the Leaves and Stem Essential Oils of Jatropha gossypifolia L. BioMed Research International. 2016;9.

25. Serrano M, Martínez-Romero D, Guillén F, et al. The addition of essential oils to MAP as a tool to maintain the overall quality of fruits. Trends in Food Science and Technology. 2008;19(9):464-471.

26. Lioglier HA. Plantas Medicinales de Puerto Rico y del Caribe. Iberoamericana de Ediciones Inc., San Juan, PR; 1990. 